通口本径と翼弦とのなす 角、 $t_{p}=2 \pi r_{p} / z \quad\left(r_{p}=\right.$ 取 付ボルト円の乎径 $=170$ $\mathrm{mm}), l$ は弦長である。 本実驗における如く翼列 外方に於て円周速度零な る場合には、 $C_{\Gamma}=u_{2} / v_{2}$ （竝に $u_{2}, v_{2}$ は夫夕翼列 內方における本均门周速 度及び輻流速度) であつ て、即方 $C_{\mathrm{N}}$ は翼列內方 にお㲿当平均速度の方向 を示すものとなる。

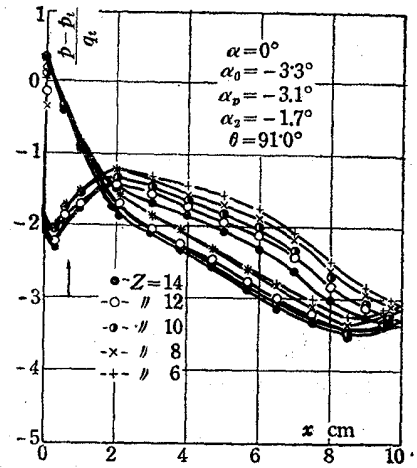

第 2 図

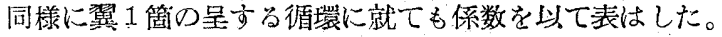

得たる結果を要約すれば次の如くで方る。

(1) 潩面上の压力分布に就ては第1 1 報 ${ }^{(6)}$ 代同じである。

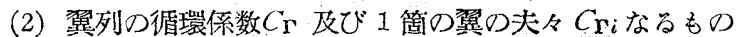
它考へそれ等の倠壳與へた。

(3) 依て $C_{\Gamma} ， C_{\Gamma_{i}}$ から翼列心受ける力崒 $M$ 並に流速方 向学求める事が出来台。

(4) 翼列中の冀の揚力係数 $C_{a}$ 仗び抗力係数 $C_{w}$ を與へ、 同様の使用に供へた。

（5）翼列中の兾に於て失速現象は殆ど見られないのは諸し き現像である。

（6）㷊列中心翼の $C_{w}$ も $\alpha_{p}$ 負なる特大である。これに

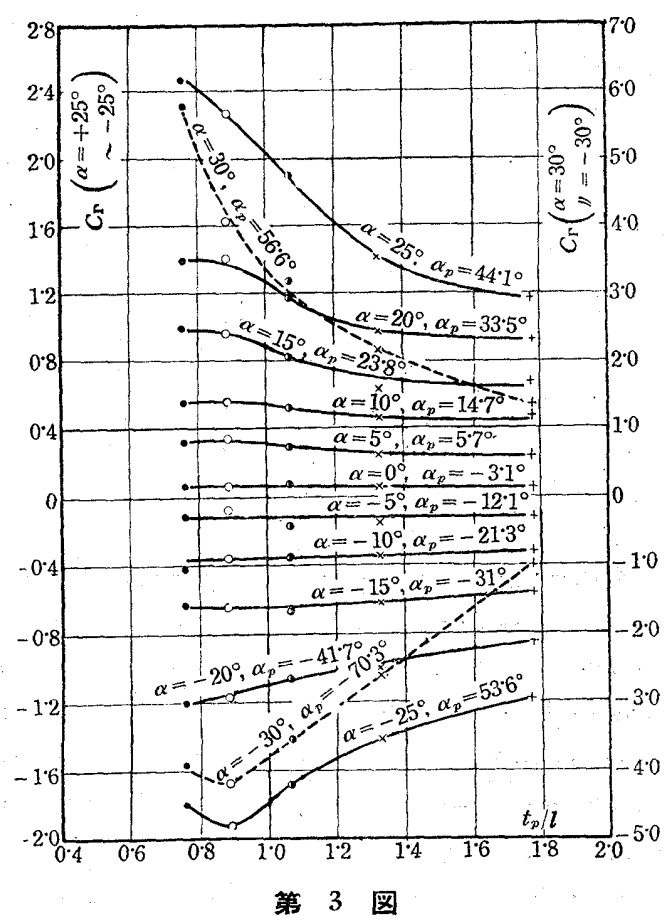

依て、案內旸根の斯る取付角をなす場合もあるが、その際は 水頭損失多がべき事を明らかにした。

(昭利 14 年 12 月.8 日受村)

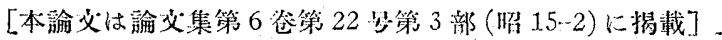

\title{
軽合金板材の疲試驗に就 $\tau^{(7)}$

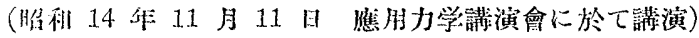

正員五十堸男 ${ }^{(8)}$ 准員深井誠吉 ${ }^{(3)}$

シェンク式振動疲試驗機 昆俅つて主として航空機用軽合金 板材の疲試驗を行つた。先づ第一に試驗条件の標潐を決定す るために熱大時效せるヂュラルミンを 試材之して最高疲强度を示方樣な試片形 牀を求め、办試片の表面条件が疲强度に 及す影響に就て試驗した。次にこれ等の 結果を基礎として二三銅合金、アルミニ ウム合金 及び マグネシウム合金 の疲强 度を求めた。而してこれ等の試驗結果を 簡單に列記すると次の様になる。即ち

（1）試驗片の形狀は軽合金を対象とし、且試驗機の容量を 考虑すれば $R=15 \mathrm{~mm}, B=20 \mathrm{~mm}, t=2 \mathrm{~mm}$ 前後が最も

(6) 東北帝国大学工学報告、12, (1936), 1. (8) Isamu IgARashr, Member. The Research Laboratory of Copper Works of Sumitomo Metal

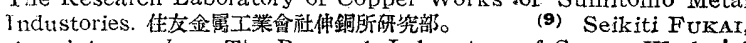
Associate member. The Research Laboratory of Copper Works!of...

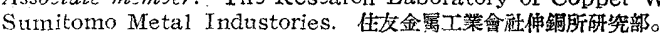

適當であらう(第 1 図参照)。

（2）試驗片の表面条件は棒忉の場合上りも頗る大きな影響 を與へ、試片の表面を極く僅か $(0.01$ $\sim 0.03 \mathrm{~mm}$ 厚さ)膘く慗により疲强度 は 9 24\% の增加を示守。故に材料 本秦の性質を比較檢討せんとする場合 には出来得る限り良好なる条件の下に 試驗す可きであるが板材は棒材と異な り、提供のま〉で使用主る事が多いか ら便用狀態に則した值を求めるために

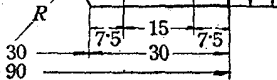

策 1 図
はそのま>で試驗する必要がある。

(3) 銅合金、アルミニウム合金 及び マグネシウム合金 13 種に就き疲試驗を行ひ、且他の機械的性質を調へた。

(昭利 14 年 12 月 9 日受付)

[本論文は論文集第 6 卷第 22 骂第 1 部（昭 15-2）に揭載] 